\title{
PENGARUH FAKTOR-FAKTOR DALAM MODIFIED UNIFIED THEORY OF ACCEPTANCE AND USE OF TECHNOLOGY 2 (UTAUT 2) TERHADAP NIAT PROSPECTIVE USERS UNTUK MENGADOPSI HOME DIGITAL SERVICES PT. TELKOM DI SURABAYA
}

\author{
Gioliano Putra ${ }^{1} \&$ Maya Ariyanti²
}

\begin{abstract}
ABSTRAK
Home Digital Service TELKOM merupakan teknologi yang penting bagi kemajuan inovasi teknologi, perekonomian negara, serta target pemerintah dan perusahaan. Tujuan dari penelitian ini adalah untuk mengetahui faktor-faktor dalam modified UTAUT2 yang memengaruhi niat prospectiv users untuk mengadopsi Home Digital Service PT TELKOM di Surabaya, seberapa besar pengaruh variabel yang memoderasi pengaruh antarkonstruk dan kemampuan prediksi modified UTAUT2 dalam memprediksi niat prospective users untuk mengadopsi Home Digital Service TELKOM di Surabaya. Dalam penelitian ini, 200 sampel dikumpulkan menggunakan kuesioner dengan teknik purposive sampling. Data dianalisis menggunakan Partial Least Square (PLS) dengan smartPLS 2.0. Berdasarkan hasil penelitian dapat diketahui bahwa seluruh konstruk eksogen memiliki pengaruh positif signifikan terhadap konstruk endogen. Hedonic motivation, social influence, price value, facilitating condition, effort expectancy, dan performance expectancy memiliki pengaruh sebesar 0,260 ; 0,$194 ; 0,138 ; 0,116 ; 0,094 ;$ dan 0,090 . Variabel rnoderasi age (usia) memoderasi pengaruh facilitating condition dan price value terhadap niat (behavioral intention) prospective users untuk mengadopsi Home Digital Service di Surabaya. Sernentara variabel moderasi jenis kelamin (gender) hanya memoderasi pengaruh performance expectancy, social influence, dan price value terhadap niat (behavioral intention) prospective users untuk mengadopsi Home Digital Service di Surabaya. Modified UTAUT2 dalam penelitian ini dapat memprediksi $54.8 \%$ behavioral intention penggunaan Home Digital Service PT. TELKOM di Surabaya.
\end{abstract}

Kata Kunci: Home Digital Service, Prospective Users, Modified UTAUT2, Telekomunikasi

\section{PENDAHULUAN}

Akses broadband yang luas dan terjangkau dapat mendorong inovasi, memberikan konstribusi terhadap produktivitas dan pertumbuhan ekonomi, serta menarik investasi asing. Saat ini, kebutuhan infrastruktur yang memperluas akses broadband menjadi sangat penting. Broadband didefinisikan oleh Akamai.com sebagai koneksi berkecepatan 4 Mbps atau lebih. Namun, berdasarkan data dari Akamai, baik rata-rata kecepatan maupun konektivitas broadband di Indonesia masih sangat rendah. Rata-rata kecepatan koneksi di Indonesia hanya mampu mencapai kisaran 1,4 Mbps dan Penetrasi broadband di Indonesia hanya 2,5\% saja. Rata-rata kecepatan koneksi Indonesia bahkan lebih rendah dari negara-negara tetangga seperti Vietnam (1,5 Mbps), Malaysia (2,3 Mbps), dan Thailand (3,3 Mbps). Begitu pula penetrasi broadband di Indonesia yang masih di bawah negara-negara tetangga seperti Malaysia (13\%) dan Thailand (26\%). 
Rendahnya penetrasi broadband dan kecepatan koneksi internet rata-rata Indonesia amat

JURNAL

MANAJEMEN

INDONESIA

Vol. 12 - No. 4

April 2013 disayangkan. Padahal, pemanfaatan potensi broadband secara optimal rnerupakan hal yang penting. Menurut World Bank, konstribusi broadband pada pertumbuhan Produk Domestik Bruto (PDB) lebih besar dibandingkan dengan layanan telekomunikasi lainnya. Dari setiap 10\% peningkatan penetrasi broadband, perekonomian diyakini akan tumbuh 1.3\%. Data yang diambil dari digitalkreatif.com mengungkapkan bahwa, broadband nirkabel dan sektor industri Indonesia yang terkait diprediksi memiliki potensi untuk mengasilkan US\$ 9,01 miliar atau sekitar 1,68\% PDB Indonesia pada tahun 2015.

Menurut Savitri (2013), saat ini pemerintah bersama TELKOM sebagai penyedia infrastruktur jaringan sedang mengembangkan broadband di Indonesia melalui Master Plan Percepatan dan Perluasan Pembangunan Ekonomi Indonesia (MP3EI). Dalam MP3EI, TELKOM telah berkomitmen untuk membangun True Broadband Nasional (20 - $100 \mathrm{Mbps}$ ) sampai dengan tahun 2015. Target pengembangan broadband pemerintah untuk akses perumahan diharapkan akan mencapai $75 \%$ pada tahun 2017. Sementara untuk akses gedung diharapkan dapat mencapai 100\% pada tahun 2017. Oleh karena itu, demi mencapai target-target pemerintah bersama TELKOM ini, kesuksesan Home Digital Service menjadi sangat penting. Pemerintah optimistis penetrasi layanan jaringan pita lebar (broadband) di Indonesia meningkat menjadi 100\% terhadap populasi penduduk pada 2015. Saat ini, penetrasi broadband di Indonesia di bawah $40 \%$ terhadap populasi. TELKOM sendiri memiliki target tahunan untuk optical transport network coverage. TELKOM memiliki target 73\% kota kabupaten pada tahun 2013 sudah dapat ter-cover jaringan True Broadband dan terus meningkat tiap tahunnya. Sehingga diharapkan pada tahun 2015 mampu mencapai 90\% kota kabupaten yang dapat menikrnati layanan True Broadband.

Sejalan dengan itu, TELKOM juga tengah membangun layanan Home Digital Service di kota-kota besar. Home Digital Service adalah sebuah layanan yang akan memenuhi berbagai kebutuhan dan keinginan untuk berkomunikasi dengan perumahan pelanggan di cara-cara yang berbeda dan lebih maju. Home Digital Service mulai beroperasi untuk mendukung upaya TELKOM dalam membangun broadband mengakses infrastruktur jaringan (broadband) di berbagai daerah. Home Digital Service TELKOM adalah produk dari teknologi true broadband itu sendiri. Jadi, dengan meningkatnya penggunaan Home Digital Service TELKOM berarti mendukung pula peningkatan penetrasi true broadband yang ditargetkan pemerintah dan TELKOM.

Kota-kota besar di Indonesia menjadi sasaran utama TELKOM dalam memperkenalkan dan memasarkan layanan Home Digital Service. Sepuluh kota besar yang menjadi target pengembangan broadband dan Home Digital Service TELKOM antara lain adalah Jakarta, Surabaya, Palembang, Medan, Bandung, Batam, Pekanbaru, Semarang, Makassar, dan Banjarmasin. Akan tetapi, sementara ini Home Digital Service TELKOM sendiri masih terpusat di Jakarta dan sekitarnya saja. Padahal targetnya adalah kota-kota besar di Indonesia. Hal tersebut membuat Surabaya menjadi target pasar yang memiliki prospective users yang potensial (Siaran Pers PT Telkom, 2010). Hal ini dikarenakan Surabaya merupakan kota terbesar kedua di Indonesia setelah Jakarta. Selain itu, Surabaya juga merupakan kota terkaya di Indonesia menurut Warta Ekonomi Tahun 2012.

Menurut Librianty (2012), selain Jakarta, Surabaya juga merupakan kota dengan densitas internet lebih tinggi dibanding dengan daerah lain. Meskipun densitas penggunaan internet di kota terbesar kedua di Indonesia ini sangat tinggi, akses broadband-nya masih rendah. Akses broadband di Surabaya baru mencapai 1,6\% pada tahun 2012. Sedangkan menurut Head of Corporate Communication PT. Telkom Tbk, Eddy Kurnia, target secara nasional pada 2014 adalah 30\%. Terlebih Surabaya hendak menjadi cyber city atau digital city, dan hal ini didukung oleh TELKOM. TELKOM saat ini tengah menjajaki kerjasama dengan REI Jawa Timur untuk mengimplementasikan Home Digital Service di perusahaan-perusahaan menengah atas di Kota Surabaya (Jajeli, 2012). 
Menurut International Telecom Union (ITU), setidaknya ada empat kriteria yang harus dipenuhi jika sebuah kota ingin dikenal sebagai kota digital. Pertama adalah konektivitas broadband, kedua adalah digital inclusion atau membuat masyarakatnya melek teknologi dan broadband, dan yang ketiga adalah inovasi. Syarat terakhir adalah pengetahuan bagi tenaga kerja sehingga dapat dioptimalkan untuk menciptakan nilai ekonomi (Suryadhi, 2011). Oleh karena itulah penelitian ini akan dilakukan di Surabaya.

Fenomena-fenomena tersebut menunjukkan bahwa Broadband dan Home Digital Service merupakan produk inovasi teknologi baru yang sangat penting bagi kernajuan inovasi teknologi dan perekonomian negara. Pemerintah bersama TELKOM tengah berupaya mengernbangkan penyelenggaraan true broadband yang berfokus pada fiber access serta penggunaan Home Digital Service dikota besar seperti Surabaya. TELKOM harus mengetahui faktor-faktor apa saja yang memengaruhi penerimaan ataupun adopsi teknologi Home Digital Service ini agar dapat memenuhi target perusahaan maupun pemerintah. Pendekatan teori/rnodel yang tepat untuk mengetahui hal tersebut adalah teori/model Unified Theory of Acceptance and use of Technology 2 (UTAUT 2). Unified Theory of Acceptance and Use of Technology 2 (UTAUT 2) tepat untuk digunakan karena teori/model ini adalah teori/model penerimaan teknologi terbaru yang merupakan unifikasi, sintesis, ataupun rangkuman dari delapan teori/model penerimaan teknologi yang telah ada sebelumnya. Tidak seperti UTAUT 1 yang konteksnya adalah organisasional, UTAUT 2 mampu menjelaskan penerimaan teknologi yang konteksnya adalah consumer use (Venkatesh et. al., 2012:157). Broadband dan Home Digital Service TELKOM itu sendiri merupakan produk inovasi teknologi yang konteksnya adalah consumer use sehingga sangat tepat diteliti dengan teori/model UTAUT 2.

UTAUT telah banyak digunakan untuk meneliti berbagai jenis inovasi teknologi di seluruh dunia baik yang bersifat organisasional (continous monitoring technology, clinical decision support, hingga sistem informasi TeNOSS TELKOM), maupun yang bersifat consumer use (mobile shopping service, mobile internet, MRT I-Pass, hingga mobile banking). Berdasarkan Sandaire (2009:26), Amin et al (2008), Yu (2012:108), Singh et al (2010) dalam Yu (2012: 108), Foon dan Fah (2012: 13), Gonzale dan Galletta (2012: 66), dan Indrawati et al (2010: 4), faktor-faktor ataupun konstruk dalam UTAUT yang antara lain adalah Performance Expectancy (PE), Effort Expectancy (EE), Social Influence (SI), dan Facilitating Condition (FC) memengaruhi Behavioral Intention (BI) dengan Age (Usia). Gender (Jenis Kelamin), Experience (Pengalaman), dan Voluntariness of Use sebagai variabel yang memoderasi hubungan antar konstruk. Berdasarkan Venkatesh et al. (2012:160), UTAUT 2 memiliki konstruk yang sama dengan UTAUT yang pertama, dengan tambahan Hedonic Motivation (HM), Price Value (PV), dan Habit (HT) sebagai konstruk eksogen dan hanya dimoderasi oleh Age (Usia), Gender (Jenis Kelamin) dan Experience (Pengalaman). Akan tetapi dalam penelitian kali ini peneliti tidak mengikutsertakan Habit dan Experience karena yang menjadi target responden adalah prospective users yang belum pernah menggunakan teknologi Home Digital Service TELKOM sehingga belum memiliki pengalaman maupun kebiasaan apapun terhadap Home Digital Service TELKOM.

Dari latar belakang tersebut, peneliti mengemukakan rurnusan masalah (problem statement), sebagai berikut: Akses Broadband dengan Home Digital Service merupakan teknologi consumer context yang penting bagi kemajuan inovasi teknologi dan perekonomian negara. Telkom perlu mengetahui apa yang menjadi faktor-faktor yang memengaruhi niat prospective users untuk mengadopsi penggunaan Home Digital Service PT. TELKOM di Surabaya agar target perusahaan dan pemerintah dapat dipenuhi.

Berdasarkan permasalahan yang telah dirumuskan di atas, tujuan utama dari penelitian ini adalah untuk mengetahui apa saja faktor-faktor dalam Modified Unified Theory of Acceptance and Use of Technology 2 (Modified UTAUT2) yang memengaruhi niat prospective users untuk mengadopsi Home Digital Service di Surabaya seberapa besar pengaruh faktorfaktor tersebut, variabel yang memoderasi antar konstruk, dan terakhir mengetahui apakah 
JURNAL

MANAJEMEN

INDONESIA

Vol. 12 - No. 4

April 2013
Modified Unified Theory of Acceptance and Use of Technology 2 (Modified UTAUT2) dapat dipakai untuk memprediksi niat prospective users untuk mengadopsi Home Digital Service di Surabaya.

\section{METODE PENELITIAN}

Metode yang digunakan dalam penelitian ini adalah metode kuantitatif, yaitu jenis penelitian yang membantu dalam generalisasi hasil penelitian berdasarkan analisis statistikal. Responden dalam penelitian ini adalah orang-orang yang berminat untuk membeli dan menggunakan Home Digital Service PT. TELKOM atau disebut juga prospective users Home Digital Service PT. TELKOM, dengan karakteristik: (1) Memiliki minat dan pengetahuan mengenai hal-hal yang berhubungan dengan Home Digital Service PT. TELKOM; (2) Pria dan wanita; (3) Bertempat tinggal di Surabaya; (4) Pendidikan minimal SMA atau yang sederajat dengan alasan responden mempunyai kemampuan untuk memahami pertanyaan-pertanyaan pada kuesioner. Pengumpulan data dilakukan dengan menggunakan kuesioner secara offline (cetak kertas).

Dari seluruh kuesioner yang telah dikumpulkan dan dipilih dengan melihat kelayakan kuesioner, peneliti memilih 200 kuesioner dari responden di Surabaya untuk diolah dan dianalisis. Hasil rekap dan koding data dari 200 responden tersebut kemudian dihitung untuk melihat karakteristik responden gambaran tanggapan responden terhadap masing-masing variabel, dan analisis PLS menggunakan SmartPLS 2.0.

\section{HASIL DAN PEMBAHASAN}

\section{a. Karakteristik Responden}

Karakteristik responden penelitian ini ditunjukkan oleh tabel 1.1 berikut ini.

\begin{tabular}{|c|c|c|}
\hline Jenis Kelamin & Jumlah Responden & Persentase \\
\hline Pria & 96 & $48 \%$ \\
\hline Wanita & 104 & $52 \%$ \\
\hline Rentang Usia & Jumlah Responden & Persentase \\
\hline 14-18 Tahun & 16 & $8 \%$ \\
\hline$>18-25$ Tahun & 84 & $42 \%$ \\
\hline$>25-36$ Tahun & 35 & $17.50 \%$ \\
\hline$>36-48$ Tahun & 39 & $19.50 \%$ \\
\hline$>48-62$ Tahun & 26 & $13 \%$ \\
\hline Lokas! & Jumiah Responden & Persentase \\
\hline Surabaya Utara & 31 & $15.50 \%$ \\
\hline Surabaya Pusat & 36 & $18 \%$ \\
\hline Sursbaya Barat & 26 & $13 \%$ \\
\hline Surabaya Timur: & 57 & $28.50 \%$ \\
\hline Surabaya Selatan & 50 & $25 \%$ \\
\hline Pendidikan & Jumlah Reponden & Persentase \\
\hline SMA & 45 & $22.50 \%$ \\
\hline Diploma/Akademi & 7 & $3.50 \%$ \\
\hline Sarjana (Si) & 120 & $60 \%$ \\
\hline S2 & 24 & $12 \%$ \\
\hline Lainnya (\$3) & 4 & $2 \%$ \\
\hline Jenis HDS & Jumlah Responden & Persentase \\
\hline HotspotWViFi & 126 & $42.14 \%$ \\
\hline Telkomvision (IPTV) & 39 & $13,04 \%$ \\
\hline Useetr & 28 & $9.35 \%$ \\
\hline Speedy Internet & 80 & $26.76 \%$ \\
\hline Speedy Home Monitoring & 9 & $301 \%$ \\
\hline Melody Online & 17 & $5.69 \%$ \\
\hline
\end{tabular}


Data responden berdasarkan jenis kelamin sengaja dicari untuk memenuhi jumlah minimum sampel yang harus dipenuhi yaitu 60 (10 x jumlah konstruk) dan jumlah iterasi yang disarankan dalam Jogiyanto (2011:85) yaitu 200 responden. Usia 14-25 tahun dikategorikan sebagai usia muda, sedangkan usia >25-62 tahun dikategorikan sebagai usia tua. Usia muda dengan rentang >18-25 tahun cenderung lebih banyak karena cenderung lebih akrab dan responsif terhadap teknologi baru. Sedangkan untuk usia tua yang dianggap lebih akrab dan responsif terhadap teknologi adalah usia yang lebih muda ( $>18-48$ tahun) karena terlahir di era teknologi. Kuesioner disebarkan di pusat keramaian seperti rnall/pusat perbelanjaan, universitas, sekolah, dan pusat keramaian lainnya. Penyebaran dilakukan sedemikian rupa karena tidak mungkin untuk mendatangi rumah per rumah dari pintu ke pintu. Pusat keramaian yang menjadi tujuan utama adalah pusat keramaian yang berada di Surabaya Timur dan Surabaya Selatan karena pada daerah tersebut lebih banyak terdapat pusat keramaian seperti mall/ pusat perbelanjaan, universitas, sekolah, dan industri. Kemudian Surabaya Pusat dan Utara juga menjadi tujuan berikutnya karena terdapat pula beberapa rnall/pusat perbelanjaan. Meskipun tidak sebanyak Surabaya Timur dan Selatan namun Surabaya Pusat dan Utara rnerupakan pusat bisnis dan perkantoran serta terdapat banyak sekolah menengah yang terkenal. Peneliti berusaha agar sebisa mungkin seluruh bagian dari Surabaya dapat terwakili dengan adil tanpa menentukan jumah tertentu untuk masing-masing bagian karena metode sampling penelitian ini adalah non-probability sampling.

Periode pengumpulan kuesioner dilakukan pada bulan Agustus-September. Penyebaran kuesioner untuk mall/pusat perbelanjaan dilakukan di akhir pecan (jumat, sabtu, dan minggu) karena merupakan periode paling ramai. Penyebaran untuk universitas dan sekolah dilakukan di antara hari kerja di mana para pelajar, mahasiswa, dosen, dan karyawan lainnya aktif beraktivitas.

Terhadap data keseluruhan dilakukan pengujian model pengukuran yang terdiri dari pengujian validitas konvergen dengan melihat outer loading, AVE, dan communality. Berikut adalah Gambar 1.1 yang menunjukkan model dan hasil pengujian measurement/outer dengan menggunakan SmartPLS:

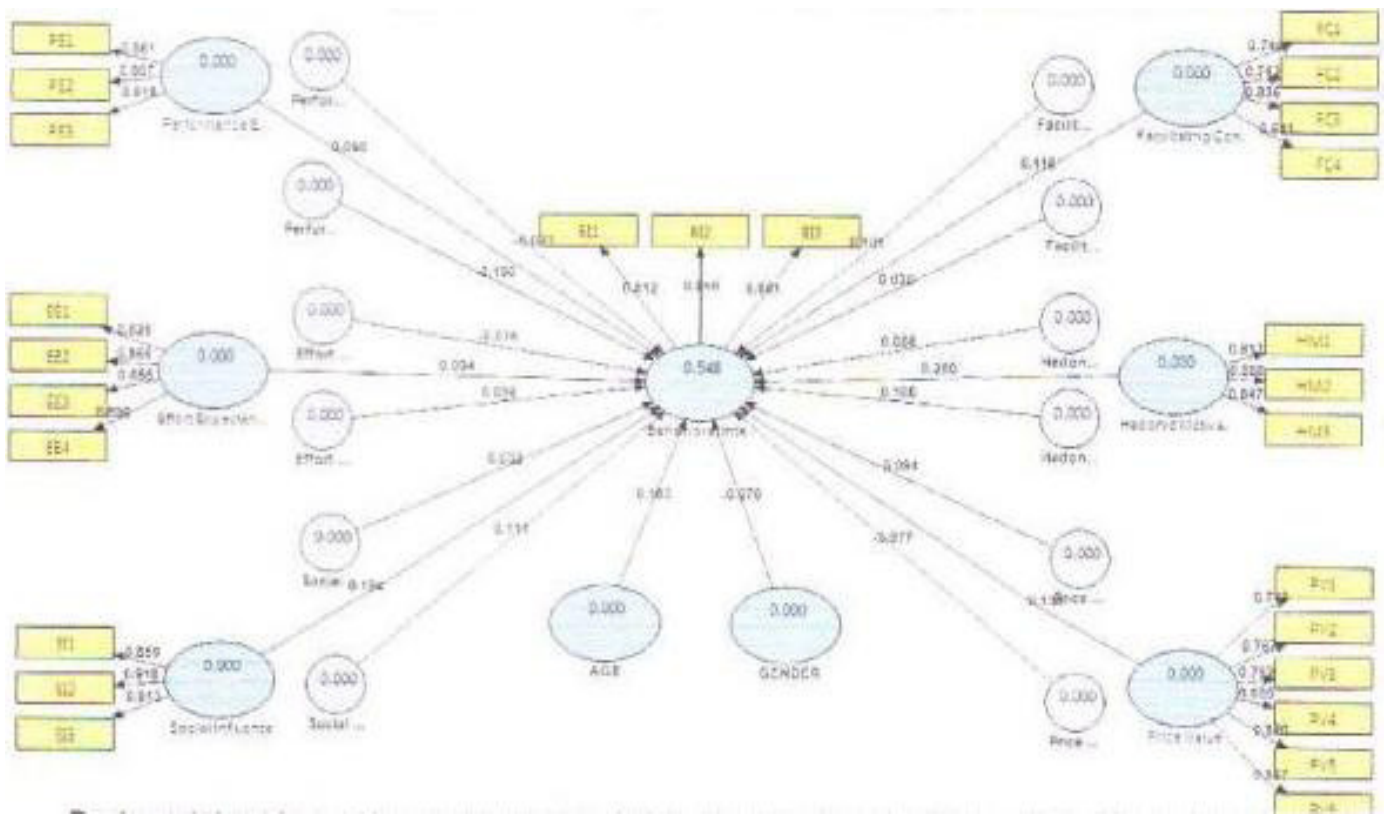

Dari model pada gambar 1.1 tersebut didapatkan hasil pengujian validitas konvergen, validitas diskriminan, dan uji reliabilitas. Penjelasan terkait hasil validitas konvergen, validitas diskriminan, dan uji reliabilitas. Berdasarkan Jogiyanto (2011:71) dan Ghozali (2008:154), validitas konvergen diuji dengan melihat outer loading, AVE, dan communality. Rule of thumb yang

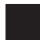

JURNAL

MANAJEMEN INDONESIA

Vol. 12 - No. 4 April 2013
Gambar 1.1 Model dan Hasil Pengujian Pengukuran dengan Menggunakan SmartPLS 2.0 
JURNAL

MANAJEMEN

INDONESIA

Vol. 12 - No. 4

April 2013 digunakan untuk validitas konvergen adalah outer loading $>0.5$, communality $>0.5$ dan average variance extracted $(A V E)>0.5$. Apabila Rule of thumb tersebut dipenuhi maka dianggap valid.

\begin{tabular}{|c|c|c|c|c|c|}
\hline Variabel & Indikator & Outer Loading & AVE & Communality & Status \\
\hline \multirow{3}{*}{ Performance Expectancy } & $\mathrm{PE}_{1}$ & 0.861 & \multirow{3}{*}{0.721} & \multirow{3}{*}{0.721} & Valid \\
\hline & $\mathrm{PE}_{2}$ & 0.867 & & & Valid \\
\hline & $P E_{3}$ & 0.818 & & & Valid \\
\hline \multirow{4}{*}{ Effort Expectancy } & $\mathrm{EE}_{1}$ & 0.828 & \multirow{4}{*}{0.735} & \multirow{4}{*}{0,735} & Valid \\
\hline & $\mathrm{EE}_{2}$ & 0.856 & & & Valid \\
\hline & $\mathrm{EE}_{3}$ & 0.855 & & & Valid \\
\hline & $\mathrm{EE}_{4}$ & 0.890 & & & Valid \\
\hline
\end{tabular}

Tabel 1.2

Uji Validitas Konvergen

\begin{tabular}{|c|c|c|c|c|c|}
\hline \multirow{3}{*}{ Social Influence } & $\mathrm{Sl}_{1}$ & 0.859 & \multirow{3}{*}{0.805} & \multirow{3}{*}{0.805} & Valid \\
\hline & $\mathrm{Sl}_{2}$ & 0.918 & & & Valid \\
\hline & $\mathrm{SI}_{3}$ & 0.913 & & & Valid \\
\hline \multirow{4}{*}{ Facilitating Conditions } & $\mathrm{FC}_{1}$ & 0.746 & \multirow{4}{*}{0.561} & \multirow{4}{*}{0.561} & Valid \\
\hline & $\mathrm{FC}_{2}$ & 0.762 & & & Valid \\
\hline & $\mathrm{FC}_{3}$ & 0.835 & & & Valid \\
\hline & $\mathrm{FC}_{4}$ & 0.641 & & & Valid \\
\hline \multirow{3}{*}{ Hedonic Motivation } & $\mathrm{HM}_{1}$ & 0.913 & \multirow{3}{*}{0.780} & \multirow{3}{*}{0.780} & Valid \\
\hline & $\mathrm{HM}_{2}$ & 0.888 & & & Valid \\
\hline & $\mathrm{HM}_{3}$ & 0.847 & & & Valid \\
\hline \multirow{6}{*}{ Price Value } & $P V_{1}$ & 0.745 & \multirow{6}{*}{0.638} & \multirow{6}{*}{0.638} & Valid \\
\hline & $\mathrm{PV}_{2}$ & 0.767 & & & Valid \\
\hline & $\mathrm{PV}_{3}$ & 0.752 & & & Valid \\
\hline & $\mathrm{PV}_{4}$ & 0.855 & & & Valid \\
\hline & $\mathrm{PV}_{5}$ & 0.820 & & & Valid \\
\hline & $\mathrm{PV}_{6}$ & 0.847 & & & Valid \\
\hline \multirow{3}{*}{ Behavioral Intention } & $\mathrm{Bl}_{1}$ & 0.812 & \multirow{3}{*}{0.711} & \multirow{3}{*}{0.711} & Valid \\
\hline & $\mathrm{Bl}_{2}$ & 0.856 & & & Valid \\
\hline & $\mathrm{Bl}_{3}$ & 0.861 & & & Valid \\
\hline
\end{tabular}

Berdasarkan Tabel 1.2 dapat dilihat bahwa dari hasil pengujian validitas konvergen didapatkan outer loading, communality dan average variance extracted (AVE) dengan nilai lebih dari 0 5. Hal tersebut menunjukkan bahwa berdasarkan pengujian validitas konvergen seluruh variabel dan item dinilai valid karena outer loading, communality dan average variance extracted (AVE) memiliki nilai lebih dari 0.5 .

Uji validitas diskriminan dinilai berdasarkan cross loading pengukuran dengan konsturknya. Metoda lain yang digunakan unluk menilai validitas diskriminan adalah dengan membandingkan akar AVE untuk setiap konstruk dengan korelasi antara konstruk dengan konstruk lainnya dalam model. Model memiliki validitas diskriminan yang cukup apabila akar AVE untuk setiap konstruk lebih besar daripada korelasi antara konstruk dengan konstruk lainnya dalam model dan cross loading terbesar berada pada konstruk yang dibentuknya. Nilai cross loading dapat dilihat pada Tabel 2.3 berikut: 


\begin{tabular}{|c|c|c|c|c|c|c|c|}
\hline \multirow{2}{*}{ Indikator } & \multicolumn{7}{|c|}{ Konstruk } \\
\cline { 2 - 8 } & $\begin{array}{c}\text { Performance } \\
\text { Expectancy }\end{array}$ & $\begin{array}{c}\text { Effort } \\
\text { Expectancy }\end{array}$ & $\begin{array}{c}\text { Social } \\
\text { Influence }\end{array}$ & $\begin{array}{c}\text { Facilitating } \\
\text { Condition }\end{array}$ & $\begin{array}{c}\text { Hedonic } \\
\text { Motivation }\end{array}$ & $\begin{array}{c}\text { Price } \\
\text { Value }\end{array}$ & $\begin{array}{c}\text { Behavioral } \\
\text { Intention }\end{array}$ \\
\hline $\mathrm{PE}_{1}$ & 0.861 & 0.439 & 0.406 & 0.299 & 0.414 & 0.341 & 0.486 \\
\hline $\mathrm{PE}_{2}$ & 0.867 & 0.438 & 0.358 & 0.325 & 0.321 & 0.393 & 0.449 \\
\hline $\mathrm{PE}_{3}$ & 0.818 & 0.363 & 0.353 & 0.269 & 0.299 & 0.454 & 0.369 \\
\hline $\mathrm{EE}_{1}$ & 0.404 & 0.828 & 0.244 & 0.340 & 0.300 & 0.242 & 0.329 \\
\hline $\mathrm{EE}_{2}$ & 0.387 & 0.856 & 0.230 & 0.240 & 0.293 & 0.262 & 0.322 \\
\hline $\mathrm{EE}_{3}$ & 0.395 & 0.855 & 0.360 & 0.304 & 0.334 & 0.299 & 0.330 \\
\hline $\mathrm{EE}_{4}$ & 0.480 & 0.890 & 0.359 & 0.376 & 0.358 & 0.389 & 0.435 \\
\hline $\mathrm{Sl}_{1}$ & 0.331 & 0.268 & 0.859 & 0.419 & 0.276 & 0.251 & 0.383 \\
\hline $\mathrm{Sl}_{2}$ & 0.405 & 0.332 & 0.918 & 0.499 & 0.293 & 0.367 & 0.471 \\
\hline $\mathrm{Sl}_{3}$ & 0.439 & 0.343 & 0.913 & 0.499 & 0.339 & 0.423 & 0.452 \\
\hline $\mathrm{FC}_{1}$ & 0.219 & 0.165 & 0.437 & 0.746 & 0.182 & 0.354 & 0.283 \\
\hline $\mathrm{FC}_{2}$ & 0.201 & 0.328 & 0.433 & 0.762 & 0.451 & 0.197 & 0.351 \\
\hline $\mathrm{FC}_{3}$ & 0.367 & 0.355 & 0.368 & 0.835 & 0.398 & 0.315 & 0.440 \\
\hline $\mathrm{FC}_{4}$ & 0.239 & 0.228 & 0.374 & 0.641 & 0.294 & 0.355 & 0.271 \\
\hline $\mathrm{HM}_{1}$ & 0.402 & 0.383 & 0.337 & 0.474 & 0.913 & 0.210 & 0.487 \\
\hline $\mathrm{HM}_{2}$ & 0.317 & 0.336 & 0.278 & 0.352 & 0.888 & 0.138 & 0.413 \\
\hline $\mathrm{HM}_{3}$ & 0.366 & 0.266 & 0.274 & 0.369 & 0.847 & 0.153 & 0.361 \\
\hline $\mathrm{PV}_{1}$ & 0.331 & 0.276 & 0.220 & 0.189 & 0.082 & 0.745 & 0.223 \\
\hline $\mathrm{PV}_{2}$ & 0.284 & 0.268 & 0.294 & 0.285 & -0.020 & 0.767 & 0.192 \\
\hline $\mathrm{PV}_{3}$ & 0.301 & 0.233 & 0.264 & 0.306 & -0.016 & 0.752 & 0.189 \\
\hline $\mathrm{PV}_{4}$ & 0.416 & 0.314 & 0.338 & 0.300 & 0.187 & 0.855 & 0.347 \\
\hline $\mathrm{PV}_{5}$ & 0.418 & 0.274 & 0.338 & 0.386 & 0.285 & 0.820 & 0.368 \\
\hline $\mathrm{PV}_{5}$ & 0.390 & 0.318 & 0.371 & 0.378 & 0.215 & 0.847 & 0.408 \\
\hline $\mathrm{Bl}_{1}$ & 0.407 & 0.317 & 0.369 & 0.350 & 0.461 & 0.215 & 0.812 \\
\hline $\mathrm{Bl}_{2}$ & 0.418 & 0.434 & 0.390 & 0.443 & 0.391 & 0.413 & 0.856 \\
\hline $\mathrm{Bl}_{3}$ & 0.484 & 0.305 & 0.474 & 0.371 & 0.370 & 0.350 & 0.861 \\
\hline & & & & & & \\
\hline
\end{tabular}

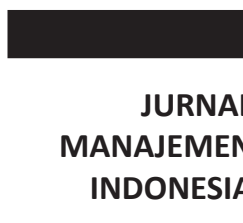

Vol. 12 - No. 4 April 2013

Berdasarkan Tabel 1.3 dapat dilihat bahwa cross loading terbesar berada pada konstruk yang dibentuknya. Sehingga dapat disimpulkan bahwa indikator-indikator penelitian memenuhi validitas diskriminan. Selain menggunakan cross loading, validitas diskriminan juga dilihat melalui akar AVE pada tabel 2.4 berikut:

\begin{tabular}{|c|c|c|c|c|c|c|c|c|c|}
\hline Toiks & AIE & 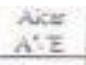 & $\begin{array}{l}\text { Portemianity } \\
\text { Eyerisand }\end{array}$ & $\begin{array}{l}\text { Efort } \\
\text { Eipermas }\end{array}$ & $\begin{array}{l}\text { Tacsa } \\
\text { Arserer }\end{array}$ & $\begin{array}{l}\text { Fat itat? } \\
\text { cudites }\end{array}$ & 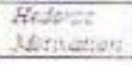 & $\begin{array}{l}\text { Price } \\
\text { Paisf }\end{array}$ & 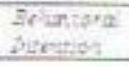 \\
\hline $\begin{array}{l}\text { Perforouare } \\
\text { Experins }\end{array}$ & $=721$ & $\Sigma 5+3$ & $2.6 \%$ & & & & & & \\
\hline $\begin{array}{l}\text { Efter: } \\
\text { Iforians? }\end{array}$ & 243 & ESZ & 42 & $1=6$ & & & & & \\
\hline $\begin{array}{l}\text { Ieria: } \\
\text { Aptoeszer }\end{array}$ & 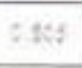 & $: 57^{\circ}$ & $3+47$ & 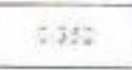 & 1.00 & & & & \\
\hline 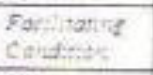 & $0 \leq 51$ & 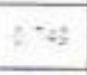 & $3: 352$ & $\mathrm{CS}^{2} 3$ & $2 \leqslant 2 \%$ & $1.0 \%$ & & & \\
\hline 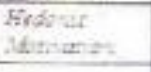 & $z-2 z$ & $:: 353$ & $: 211$ & $z z^{\prime}$ & 6.338 & $=458$ & 1.50 & & \\
\hline Pnertiater & 7.538 & $\therefore 35$ & $6+13$ & 2.:311 & $2.23 \%$ & 2Jit & 8172 & tiste & \\
\hline 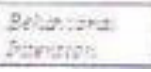 & $:-t 1$ & 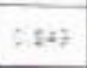 & * $: 3:$ : & 5417 & $5+4$ & $=251$ & $2-32$ & $335 \%$ & 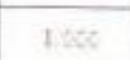 \\
\hline
\end{tabular}

Tabel 1.4

Akar AVE dan Korelasi Antar Konstruk

Berdasarkan Tabet 1.4 dapat terlihat bahwa akar AVE untuk setiap konstruk lebih besar daripada korelasi antara konstruk dengan konstruk lainnya dalam model sehingga dinyatakan valid dalam pengujian validitas diskriminan. Hasil pengujian validitas diskriminan menunjukkan bahwa baik cross loading maupun akar AVE memenuhi rule of thumb sehingga dinyatakan valid.

Selain uji validitas, PLS juga melakukan uji reliabilitas untuk mengukur konsistensi internal alat ukur. Uji reliabilitas dalam PLS dapat menggunakan Composite reliability. Composite reliability mengukur nilai sesungguhnya reliabilitas suatu konstruk. Namun composite reliability 
JURNAL

MANAJEMEN

INDONESIA

Vol. 12 - No. 4

April 2013

Tabel 1.5

Nilai Composite Reliability dinilai lebih baik dalam mengestimasi konsistensi internal suatu konstruk. Rule of thumb nilai composite realibility harus lebih besar dari 0,7 meskipun nilai 0,6 masih dapat diterima (Hair et al.,. 2008). Namun sesungguhnya uji konsistensi internal tidak mutlak untuk dilakukan karena konstruk yang valid adalah konstruk yang reliabel, sebaliknya konstruk yang reliabel belum tentu valid. Hasil pengujian reliabilitas dengan melihat nilai composite reliability dapat dilihat pada Tabel 2.5 berikut:

\begin{tabular}{|c|c|c|c|}
\hline Konstruk & $\begin{array}{c}\text { Nilai } \\
\text { Composite Reliability }\end{array}$ & $\begin{array}{c}\text { Rule of } \\
\text { thumb }\end{array}$ & Status \\
\hline Performance Expectancy & 0.886 & & Reliabel \\
\hline Effort Expectancy & 0.917 & & Reliabel \\
\hline Social Influence & 0.925 & \multirow{4}{*}{0.7} & Reliabel \\
\hline Facilitating Condition & 0.835 & Reliabel \\
\hline Hedonic Motivation & 0.914 & & Reliabel \\
\hline Price Value & 0.913 & & Reliabel \\
\hline Behavioral Intention & 0.881 & & Reliabel \\
\hline
\end{tabular}

Berdasarkan Tabel 1.5 dapat dilihat bahwa nilai composite reliability seluruh variabel lebih dari 0,7. Karena nilai composite reliability seluruh konstruk lebih dari 0,7 maka keseluruhan konstruk dinyatakan reliabel. Sehingga dapat disimpulkan bahwa hasil pengujian model pengukuran (measurement/outer model) dinyatakan valid dan reliabel seluruhnya.

Setelah melakukan pengujian model pengukuran, dalam Partial Least Square (PLS) dilakukan pengujian model structural. Model structural dalam PLS dievaluasi dengan menggunakan $\mathrm{R}^{2}$ untuk konstruk dependen. Sementara nilai koefisien path atau t-values tiap path untuk uji signifikansi antar konstruk dalam model structural. Gambar dan hasil model structural dapat dilihat pada Gambar 1.2 berikut:
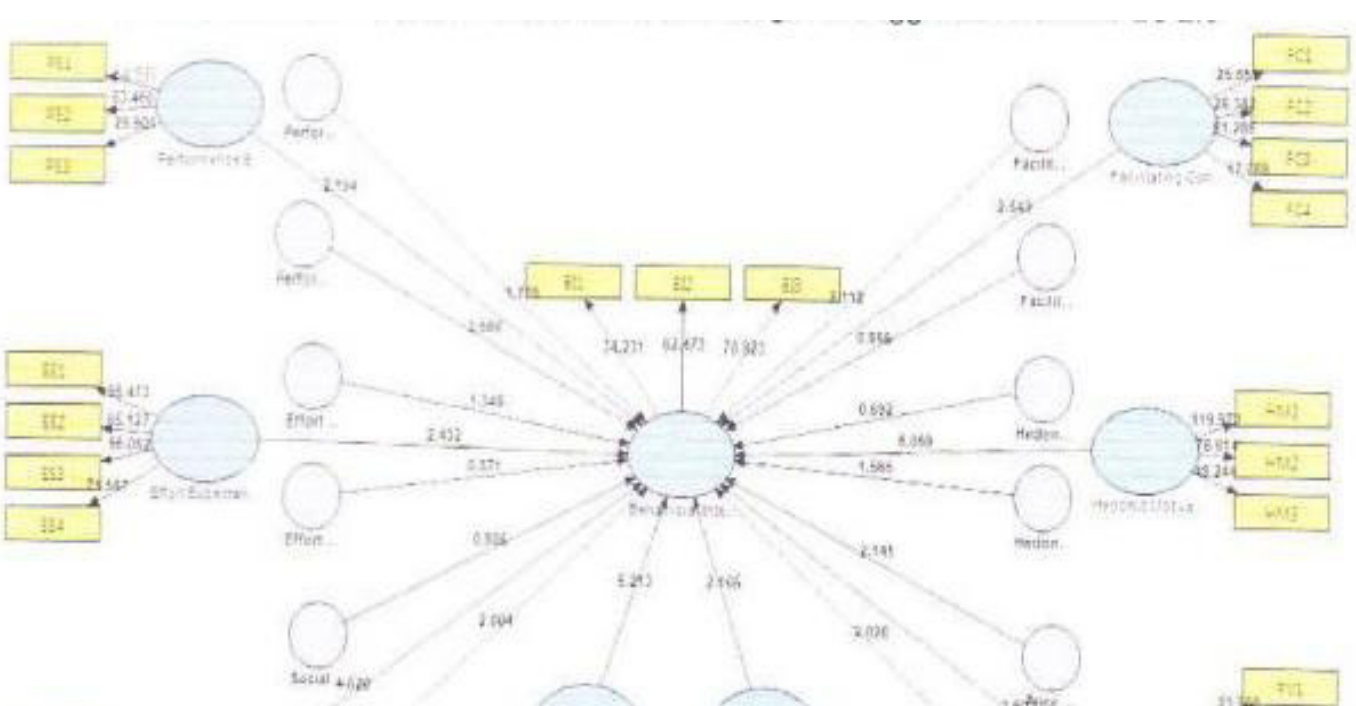

Gambar 1.2

Model dan Hasil

Pengujian Model

Struktural dengan

Menggunakan SmartPLS 2.0
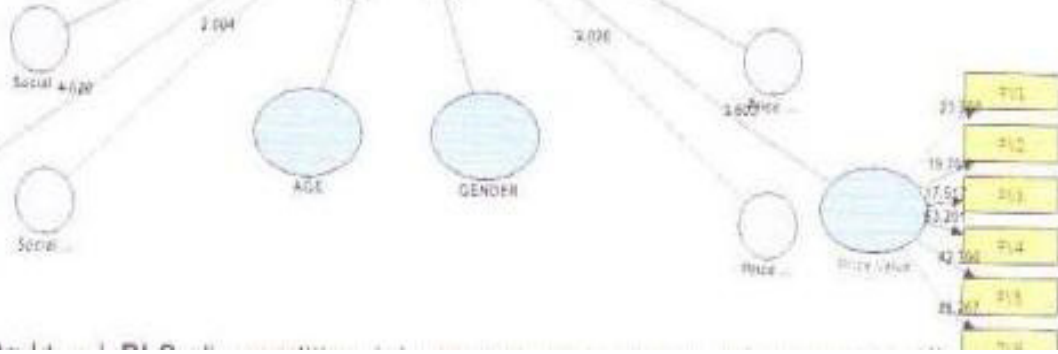

Dalam model structural PLS di penelitian ini, pertama-tama akan menguji Nilai $\mathrm{R}^{2}$. Nilai $\mathrm{R}^{2}$ digunakan untuk mengukur tingkat variasi perubahan variabel independen terhadap variabel dependen. Semakin tinggi nilai $\mathrm{R}^{2}$ berarti semakin baik model prediksi dari penelitian yang 
diajukan. Berdasarkan Yamin dan Kurniawan (2011:21), Kriteria batasan nilai $\mathrm{R}^{2}$ ini digolongkan dalam tiga klasifikasi, yaitu nilai $R^{2} 0.67,0.33,0.19$ sebagai subtansial, moderat dan lemah. Nilai R-square dalam penelitian ini dapat dilihat pada Tabel 1.6 berikut:

\begin{tabular}{|l|l|}
\hline Konstruk Endogen & Nilai R-Square \\
\hline Behavioral Intention & 0.548 \\
\hline
\end{tabular}

Berdasarkan Tabel 1.6 dapat terlihat bahwa nilai R-Square dalam penelitian ini adalah 0.548 , artinya prosentase besarnya behavioral intention yang dapat dijelaskan oleh performance expectancy, effort expectancy, social influence, facilitating condition, hedonic motivation, dan price value adalah sebesar $54,8 \%$. Sedangkan $45,2 \%$ dijelaskan oleh variabel lain yang tidak diteliti di dalam penelitian ini. Beberapa variabel lain yang tidak diteliti dalam penelitian ini antara lain adalah variabel-variabel dari teori-teori sebelumnya seperti: teori IDT (relative advantage, compatibility, complexity, triability, observability), teori MPCU (job-fit, complexity, long-term consequences, affect toward use), teori SCT (outcome-expectation performance, outcomeexpectation personal, self-efficacy, affect, dan anxiety), teori TAM (perceived usefulness, perceived ease of use, output quality, result demonstrability, job relevance, image). Selain itu dapat pula menambahkan variabel-variabelpengembangan teori lainnya seperti content, trust in company, trust in technology, perceived credibility, perceived financial cost, switching cost, dan user satisfaction. Hal tersebut menunjukkan bahwa Modified UTAUT 2 dalam penelitian ini dapat memprediksi 54.8\% behavioral intention penggunaan Home Digital Service PT. TELKOM di Surabaya. Kemampuan prediksi Modified UTAUT 2 dengan nilai R-Square sebesar 0.548 atau $54.8 \%$ tersebut termasuk ke dalam kategori moderat.

Setelah melakukan Uji Nilai $\mathrm{R}^{2}$ dilakukan Uji kausalitas dan efek moderasi Uji kausalitas antar konstruk dan efek moderasi pada pengujan model struktural PLS dilihat melalui nilai koefisien path atau t-values tiap path untuk uji signifikansi antar konstruk dalarn model struktural. Skor koefisien path atau inner model yang ditunjukkan oleh T-statistic harus di atas 1,96 untuk hipotesis dua ekor (two-tailed) untuk pengujian hipotesis pada alpha $(\alpha)$ 5 persen. Hasil uji T (kausalitas dan efek moderasi) danpengujian hipotesis dapat dilihat pada Tabel 1.7 berikut:

\begin{tabular}{|c|c|c|c|c|}
\hline Hipotesis & Pengaruh & $\begin{array}{l}\text { Koefisien } \\
\text { Path }\end{array}$ & $\begin{array}{c}t- \\
\text { statistic }\end{array}$ & Keterangan \\
\hline $\mathrm{H}_{1}$ & $\begin{array}{c}\text { Performance Expectancy } \rightarrow \text { Behavioral } \\
\text { Intention }\end{array}$ & 0.090 & 2.194 & diterima \\
\hline $\mathrm{H}_{2}$ & Effort Expectancy $\rightarrow$ Behavioral Intention & 0.094 & 2.432 & diterima \\
\hline $\mathrm{H}_{3}$ & Social Influence $\rightarrow$ Behavioral Intention & 0.194 & 4,620 & diterima \\
\hline $\mathrm{H}_{4}$ & Facilitating Condition $\rightarrow$ Behavioral Intention & 0.116 & 2.543 & diterima \\
\hline $\mathrm{H}_{5}$ & Hedonic Motivation $\rightarrow$ Behavioral Intention & 0.260 & 6.059 & diterima \\
\hline $\mathrm{H}_{6}$ & Price Value $\rightarrow$ Behavioral Intention & 0.138 & 3.603 & diterima \\
\hline $\mathrm{H}_{7}$ & $\begin{array}{c}\text { Performance Expectancy* Age } \rightarrow \text { Behavioral } \\
\text { Intention }\end{array}$ & -0.093 & 1.735 & ditolak \\
\hline $\mathrm{H}_{8}$ & $\begin{array}{c}\text { Performance Expectancy*Gender } \rightarrow \text { Behavioral } \\
\text { Intention }\end{array}$ & -0.190 & 3.566 & diterima \\
\hline $\mathrm{H}_{9}$ & Effort Expectancy*Age $\rightarrow$ Behavioral Intention & -0.076 & 1.348 & ditolak \\
\hline $\mathrm{H}_{10}$ & $\begin{array}{c}\text { Effort Expectancy*Gender } \rightarrow \text { Behavioral } \\
\text { Intention }\end{array}$ & 0.036 & 0.871 & ditolak \\
\hline$H_{11}$ & Social Influence "Age $\rightarrow$ Behavioral Intention & 0.032 & 0.806 & ditolak \\
\hline $\mathrm{H}_{12}$ & Social Influence "Gender $\rightarrow$ Behavioral Intention & 0.111 & 2.004 & diterima \\
\hline$H_{13}$ & $\begin{array}{c}\text { Facilitating Condition *Age } \rightarrow \text { Behavioral } \\
\text { Intention }\end{array}$ & 0.101 & 2.112 & diterima \\
\hline$H_{14}$ & $\begin{array}{l}\text { Facilitating Condition *Gender } \rightarrow \text { Behavioral } \\
\text { Intentinn }\end{array}$ & -0.030 & 0.656 & ditolak \\
\hline $\mathrm{H}_{16}$ & $\begin{array}{c}\text { Hedonic Motivation * Gender } \rightarrow \text { Behavioral } \\
\text { Intention }\end{array}$ & 0.108 & 1.566 & ditolak \\
\hline $\mathrm{H}_{17}$ & Price Value *Age $\rightarrow$ Behavioral Intention & 0.094 & 2.141 & diterima \\
\hline $\mathrm{H}_{18}$ & Price Value "Gender $\rightarrow$ Behavioral Intention & -0.077 & 2.028 & diterima \\
\hline
\end{tabular}

JURNAL

MANAJEMEN INDONESIA

Vol. 12 - No. 4 April 2013

Tabel 1.6 Nilai R-Square
Tabel 1.7

Hasil Uji T (Kausalitas dan Efek Moderasi) dan Pengujian Hipotesis 
JURNAL

MANAJEMEN INDONESIA

Vol. 12 - No. 4

April 2013
Berdasarkan Tabel 1.8 dapat diketahui bahwa hipotesis-hipotesis yang didukung dan tidak didukung adalah sebagai berikut:

\begin{tabular}{|c|c|c|}
\hline Hipotesis & Pengaruh & Keterangan \\
\hline 1 & $\begin{array}{c}\text { Ekspektasi kinerja (performance expectancy) berpengaruh positif } \\
\text { terhadap niat perilaku (behavioral intention) untuk mengadopsi Home } \\
\text { Digital Service di Surabaya. }\end{array}$ & Didukung \\
\hline 2 & $\begin{array}{l}\text { Ekspektasi usaha (effort expectancy) berpengaruh positif terhadap niat } \\
\text { perilaku (behavioral intention) untuk mengadopsi Home Digital Service di } \\
\text { Surabaya. }\end{array}$ & Didukung \\
\hline 3 & $\begin{array}{c}\text { Pengaruh sosial (social influence) berpengaruh positif terhadap niat } \\
\text { perilaku (behavioral intention) untuk mengadopsi Home Digital Service di } \\
\text { Surabaya. }\end{array}$ & Didukung \\
\hline 4 & $\begin{array}{c}\text { Kondisi yang memfasilitasi (facilitating conditions) berpengaruh positif } \\
\text { terhadap niat perilaku (behavioral intention) untuk mengadopsi Home } \\
\text { Digital Service di Surabaya. }\end{array}$ & Didukung \\
\hline 5 & $\begin{array}{l}\text { Motivasi Hedonis (Hedonic Motivation) berpengaruh positif terhadap niat } \\
\text { perilaku (behavioral intention) untuk mengadopsi Home Digital Service di } \\
\text { Surabaya. }\end{array}$ & Didukung \\
\hline 6 & $\begin{array}{c}\text { Nilai Harga (Price Value) berpengaruh positif terhadap niat perilaku } \\
\text { (behavioral intention) untuk mengadopsi Home Digital Service di } \\
\text { Surabaya. }\end{array}$ & Didukung \\
\hline 7 & $\begin{array}{c}\text { Hubungan ekspektasi kinerja (performance expectancy) terhadap niat } \\
\text { perilaku (behavioral intention) untuk mengadopsi Home Digital Service di } \\
\text { Surabaya dimoderasi oleh usia (age). }\end{array}$ & $\begin{array}{l}\text { Tidak } \\
\text { didukung }\end{array}$ \\
\hline \multirow[t]{2}{*}{8} & $\begin{array}{l}\text { Hubungan ekspektasi kinerja (performance expectancy) terhadap niat } \\
\text { perilaku (behavioral intention) untuk mengadopsi Home Digital Service di }\end{array}$ & Didukung \\
\hline & Surabaya dimoderasi oleh jenis kelamin (gender). & \\
\hline 9 & $\begin{array}{c}\text { Hubungan ekspektasi usaha (effort expectancy) terhadap niat perilaku } \\
\text { (behavioral intention) untuk mengadopsi Home Digital Service di } \\
\text { Surabaya dimoderasi oleh usia (age). }\end{array}$ & $\begin{array}{l}\text { Tidak } \\
\text { didukung }\end{array}$ \\
\hline 10 & $\begin{array}{l}\text { Hubungan ekspektasi usaha (effort expectancy) terhadap niat perilaku } \\
\text { (behavioral intention) untuk mengadopsi Home Digital Service di } \\
\text { Surabaya dimoderasi oleh jenis kelamin (gender). }\end{array}$ & $\begin{array}{l}\text { Tidak } \\
\text { didukung }\end{array}$ \\
\hline 11 & $\begin{array}{c}\text { Hubungan Pengaruh Sosial (social influence) terhadap niat perilaku } \\
\text { (behavioral intention) untuk mengadopsi Home Digital Senvice di } \\
\text { Surabaya dimoderasi oleh usia (age). }\end{array}$ & $\begin{array}{l}\text { Tidak } \\
\text { didukung }\end{array}$ \\
\hline 12 & $\begin{array}{c}\text { Hubungan Pengaruh sosial (social influence) terhadap niat perilaku } \\
\text { (behavioral intention) untuk mengadopsi Home Digital Service di } \\
\text { Surabaya dimoderasi oleh jenis kelamin (gender). }\end{array}$ & Didukung \\
\hline 13 & $\begin{array}{l}\text { Hubungan kondisi yang memfasilitasi (facilitating conditions) terhadap } \\
\text { niat perilaku (behavioral intention) untuk mengadopsi Home Digital } \\
\text { Service di Surabaya dimoderasi oleh usia (age). }\end{array}$ & Didukung \\
\hline 14 & $\begin{array}{l}\text { Hubungan kondisi yang memfasilitasi (facilitating conditions) terhadap } \\
\text { niat perilaku (behavioral intention) untuk mengadopsi Home Digital } \\
\text { Service di Surabaya dimoderasi oleh jenis kelamin (gender). }\end{array}$ & $\begin{array}{l}\text { Tidak } \\
\text { didukung }\end{array}$ \\
\hline 15 & $\begin{array}{c}\text { Hubungan Motivasi Hedonis (Hedonic Motivation) terhadap niat perilaku } \\
\text { (behavioral intention) untuk mengadopsi Home Digital Service di } \\
\text { Surabaya dimoderasi oleh usia (age). }\end{array}$ & $\begin{array}{l}\text { Tidak } \\
\text { didukung }\end{array}$ \\
\hline 16 & $\begin{array}{l}\text { Hubungan Motivasi Hedonis (Hedonic Motivation) terhadap niat perilaku } \\
\text { (behavioral intention) untuk mengadopsi Home Digital Service di } \\
\text { Surabaya dimoderasi oleh jenis kelamin (gender). }\end{array}$ & $\begin{array}{l}\text { Tidak } \\
\text { didukung }\end{array}$ \\
\hline 17 & $\begin{array}{c}\text { Hubungan Nilai Harga (Price Value) terhadap niat perilaku (behavioral } \\
\text { intention) untuk mengadopsi Home Digital Service di Surabaya } \\
\text { dimoderasi oleh usia (age). }\end{array}$ & Didukung \\
\hline 18 & $\begin{array}{c}\text { Hubungan Nilai Harga (Price Value) terhadap niat perilaku (behavioral } \\
\text { intention) untuk mengadopsi Home Digital Service di Surabaya } \\
\text { dimoderasi oleh jenis kelamin (gender). }\end{array}$ & Didukung \\
\hline
\end{tabular}


Tabel 1.7 dan 1.8 menunjukkan bahwa hipotesis penelitian yang didukung adalah hipotesis 1,2,3,4,5,6,8,12,13,17, dan 18. Sementara hipotesis selain itu tidak didukung. Hasil tersebut menjelaskan bahwa seluruh pengaruh konstruk eksogen (performance expectancy, effort expectany, social influence, facilitating condition, hedonic motivation, dan price value) terhadap konstruk endogen (behavioral intention) memiliki nilai t-statistics yang lebih dari 1.96 dan koefisien path yang positif. Sehingga terbukti bahwa performance expectancy, effort expectancy, social influence, facilitating condition, hedonic motivation, dan price value memiliki pengaruh positif signifikan terhadap behavioral intention. Hal tersebut berarti semakin tinggi penilaian atau anggapan responden terhadap performance expectancy, effort expectancy, social influence, facilitating condition, hedonic motivation, dan price value Home Digital Service PT. TELKOM maka semakin tinggi pula niat responden untuk menggunakan Home Digital Service PT. TELKOM. Hasil ini sesuai dengan penelitian-penelitian sebelumnya seperti Venkatesh et.al. (2012), Yu (2012), serta Gonzalez dan Galletta (2012). Sehingga PT. TELKOM sebaiknya berusaha membuat Home Digital Service PT. TELKOM dapat memiliki kinerja yang unggul dan member manfaat setinggi-tingginya kepada konsumen. Selain itu, Home Digital Service PT. TELKOM harus mudah digunakan, menyenangkan dan menghibur, memiliki harga sesuai dengan kantong konsumen serta sesuai dengan manfaat yang diberikan. Tidak kalah penting juga PT. TELKOM harus menyediakan layanan edukasi, informasi, dan bantuan yang terpadu dan handal kepada konsumen terkait penggunaan Home Digital Service PT. TELKOM. besar pengaruh masing-masing konstruk eksogen adalah sebagai berikut:

\begin{tabular}{|c|c|c|}
\hline Peringkat & Pengaruh & Koefisien Path \\
\hline 1 & Hedonic Motivation $\rightarrow$ Behavioral Intention & 0.260 \\
\hline 2 & Social Influence $\rightarrow$ Behavioral Intention & 0.194 \\
\hline 3 & Price Value $\rightarrow$ Behavioral Intention & 0.138 \\
\hline 4 & Facilitating Condition $\rightarrow$ Behavioral Intention & 0.116 \\
\hline 5 & Effort Expectancy $\rightarrow$ Behavioral Intention & 0.094 \\
\hline 6 & Performance Expectancy $\rightarrow$ Behavioral Intention & 0.090 \\
\hline
\end{tabular}

Tabel 1.9 menunjukkan bahwa hedonic motivation memiliki pengaruh terbesar di antara konstruk eksogen lainnya dengan koefisien path sebesar 0,260. Sementara social influence memiliki pengaruh terbesar kedua dengan koefisien path sebesar 0,194. Pengaruh terbesar ketiga, keempat dan kelima adalah price value, facilitating condition, dan effort expectancy dengan koefisien 0,138, 0,116, 0,094. Terakhir, performance expectancy adalah konstruk eksogen yang memiliki pengaruh terkecil dengan koefisien path 0,090 saja. Angka-angka koefisien path pada konstruk-konstruk tersebut memiliki arti sebagai berikut:

a. Hedonic motivation $=0.260$ artinya, besar pengaruh variabel hedonic motivation terhadap behavioral intention prospective users Home Digital Service PT. TELKOM adalah sebesar 0.260. Hal ini berarti jika hedonic motivation meningkat satu satuan maka behavioral intention akan meningkat 0.260 satuan.

b. Social Influence $=0.194$ artinya, besar pengaruh variabel social influence terhadap behavioral intention prospective users Home Digital Service PT. TELKOM adalah sebesar 0.194. Hal ini berarti jika social influence meningkat satu satuan maka behavioral intention akan meningkat 0.194 satuan.

c. $\quad$ Price value $=0.138$ artinya, besar pengaruh variabel price value terhadap behavioral intention prospective users Home Digital Service PT. TELKOM adalah sebesar 0.138. Hal ini berarti jika price value meningkat satu satuan maka behavioral intention akan rneningkat 0.138 satuan.

d. Facililating condition $=0.116$, artinya besar pengaruh variabel facilitating condition terhadap behavioral intention prospective users Home Digital Service PT. TELKOM
JURNAL

MANAJEMEN INDONESIA

Vol. 12 - No. 4 April 2013

Tabel 1.9

Besar Pengaruh dan Peringkat Besar Pengaruh Konstruk Eksogen Terhadap Konstruk Endogen 
JURNAL

MANAJEMEN

INDONESIA

Vol. 12 - No. 4

April 2013 adalah sebesar 0.116 . Hal ini berarti jika facilitating condition meningkat satu satuan maka behavioral intention akan meningkat 0.116 satuan.

e. Effort expectancy $=0.094$ artinya, besar pengaruh variabel effort expectancy terhadap behavioral intention prospective users Home Digital Service PT. TELKOM adalah sebesar 0.094. Hal ini berarti jika effort expectancy neningkat satu satuan maka behavioral intention akan meningkat 0.094 satuan.

f. Performance expectancy $=0.090$ artinya, besar pengaruh variabel performance expectancy terhadap behavioral intention prospective users Home Digital Service PT. TELKOM adalah sebesar 0,090. Hal ini berarti jika performance expectancy meningkat satu satuan maka behavioral intention akan meningkat 0.090 satuan.

Berdasarkan hasil tersebut, Home Digital Service PT. TELKOM sebaiknya mengutamakan aspek-aspek hedonis yang menghibur, menyenangkan, dan dapat dinikrnati oleh konsumen. Hal ini dapat dilakukan dengan memberikan konten-konten menarik yang up to-date di setiap layanannya baik IPTV/UseeTV, Speedy, Hotspot/Wifi, dan layanan lain. TELKOM dapat melengkapi layanan Home Digital Service seperti IPTV/USeeTV dengan film-film box-office terbaru yang baru saja tayang di bioskop, program-program reality show populer baik di dalam maupun luar negeri seperti TopGear dan Running Man. Selain itu IPTV/USeeTV TELKOM juga dapat menampilkan acara-acara music populer, siaran langsung pertandingan olah raga terlengkap, liputan-liputan eksklusif, dan program-program populer lainnya baik dari dalam maupun luar negeri. Kemudian Melody Online harus memiliki koleksi musik yang lengkap dan up-to-date dari musisi luar maupun dalam negeri. Kini cover-songs video di youtube mulai marak dan digemari sehingga akan sangat baik bila Melody Online memfasilitasi konsumen untuk mengunduh musik-musik tersebut dengan format Mp3 misalnya.

Selain aspek hedonis, Home Digital Service TELKOM juga harus memperhatikan aspekaspek sosial di mana I ingkungan, teman, dan keluarga dapat memengaruhi seseorang untuk menggunakan layanan teknologi tersebut. Jadi selain memiliki konten-konten menarik yang lengkap dan up-to-date akan lebih baik lagi bila TELKOM memberikan ruang dan sarana lagi konsumennya untuk sharing (berbagi) saling bercerita satu sama lain, dan memberikan opini terkait konten dan layanan itu sendiri. Bahkan sebaiknya dari ruang atau sarana tersebut konsumen dapat merekomendasikannya kepada teman-teman yang lain, orang tua ataupun saudara. Hal-hal tersebut dapat dilakukan dengan cara menyediakan kolom komentar di setiap konten, tombol, likes, dan panel sharing di mana konsumen dapat memilih media sosial (facebook, twitter, path, pinterest, instagrarn, dsb) yang mereka suka untuk berbagi dan menginformasikan komentar ataupun konten tersebut. Selain itu Home Digital Service PT. TELKOM harus memiliki manajemen media sosial yang sangat baik dan harus mampu menciptakan viral marketing yang efektif sehingga tercipta lingkungan sosial yang saling membicarakan dan merekomendasikan Home Digital Service PT. TELKOM baik teknologi, layanan, maupun konten-konten di dalamnya.

Selain itu sebaiknya TELKOM juga memperhatikan strategi harga untuk Home Digital Service PT. TELKOM. Harga yang dibebankan pada konsumen harus sesuai dengan manfaat dan kualitas yang diterima konsumen. Strategi dengan memberikan speedy card per hari yang lebih murah disbanding berlangganan sebulan misalnya dapat menjadi salah satu solusi. Paket-paket layanan dengan harga bervariasi yang ditujukan untuk segmen-segmen berbeda juga penting karena dengan begitu Home Digital Service PT. TELKOM dapat memberikan nilai harga yang lebih baik bagi para konsumen. Layanan dan harga akan berbeda untuk konsumen mahasiswa, ibu rumah tangga, atau pebisnis. Paket bundling juga dapat menjadi solusi dengan membundling layanan-layanan tertentu dengan harga yang lebih bersahabat.

Kemudian kondisi yang memfasilitasi juga harus diperhatikan TELKOM. TELKOM harus dapat menyediakan service center yang mampu dengan baik memberikan informasi, edukasi, dan 
bantuan-bantuan terkait penggunaan teknologi dan layanan Home Digital Service PT. TELKOM. Service centre ini sebaiknya dapat dihubungi dengan berbagai cara baik melalui media sosial, telepon, sms, e-mail, dan lain sebagainya. Service centre TELKOM harus tanggap dan cekatan serta dapat dihandalkan dalam membantu segala kebutuhan konsumen terkait penggunaan Home Digital Service PT. TELKOM. Kondisi yang memfasilitasi tidak hanya dilihat dari hal tersebut saja, tetapi juga kecocokan (compatibility) Home Digital Service PT. TELKOM dengan teknologiteknologi milik konsumen yang sudah ada sebelumnya. Jadi Home Digital Service PT. TELKOM harus dapat dioperasikan di notebook, televisi, atau gadget lain milik konsumen. Sehingga konsumen tidak perlu repot membeli piranti atau gadget baru untuk menikmati layanan Home Digital Service PT. TELKOM seperti IPTV/UseeTV, Melody Online, Hotspot/Wifi, dan Speedy Internet up to $100 \mathrm{Mbps}$.

Tidak kalah penting juga Home Digital Service PT. TELKOM harus mudah digunakan, dipelajari, dan dimengerti. TELKOM harus menyediakan informasi lengkap berupa buku panduan ataupun informasi penggunaan secara online (informasi/tutorial di website). Edukasi saat ini instalasi Home Digital Service PT. TELKOM kepada konsumen juga sebaiknya dilakukan sampai konsumen dapat menguasai penggunaan Home Digital Service PT. TELKOM dengan baik. Selain mudah digunakan, Home Digital Service PT. TELKOM juga sebaiknya bermanfaat bagi kehidupan konsumen, meningkatkan produktivitas kerja, dan membantu menyelesaikan pekerjaan dengan lebih cepat. Oleh karena itu, Home Digital Service PT. TELKOM harus memiliki kualitas jaringan dan layanan yang baik dan minim downtime. Kecepatan akses pun harus sesuai janji. Apabila memang berkecepatan $100 \mathrm{Mbps}$ maka realita pun harus secepat itu. Konten-konten pun harus menunjang pekerjaan konsumen. Sehingga akses internet cepat dan handal untuk memperoleh berbagai informasi/data terkait pekerjaan konsumen dapat berjalan lebih baik dari sebelumnya. Karena apabila akses tidak baik maka kegiatan-kegiatan terkait aspek hedonis maupun sosial juga akan terganggu sehingga membuat konsumen akan merasa kecewa.

Selain itu Tabel 2.7 juga menunjukkan bahwa variabel moderator gender (jenis kelamin) hanya terbukti signifikan rnemoderasi pengaruh performance expectancy, social influence, dan price value terhadap behavioral intention. Efek moderasi gender pada pengaruh performance expectancy dan price value terhadap behavioral intention menghasilkan koefisien path yang negatif, maka dapat dikatakan bahwa efek moderasi gender pada pengaruh performance expectancy dan price value terbukti negative signifikan. Sementara pengaruh effort expectancy, facilitating condition, hedonic motivation tidak dimoderasi gender dan terbukti tidak signifikan.

Variabel moderator gender (jeris kelamin) hanya memoderasi pengaruh performance expectancy, social influence, dan price value terhadap behavioral intention dengan t-statistics lebih dari 1.96 sehingga terbukti signifikan. Efek moderasi gender pada pengaruh performance expectancy dan price value terhadap behavioral intention menghasilkan koefisien path yang negative, maka dapat dikatakan bahwa efek rnoderasi gender pada pengaruh performance expectancy dan price value terbukti negative signifikan. Sementara pengaruh effort expectancy, facilitating condition, hedonic motivation tidak dimoderasi gender karena memiliki t-statistics di bawah 1.96 sehingga terbukti tidak signifikan.

Kemudian variabel moderator age (usia) hanya memoderasi pengaruh variabel facilitating condition dan price value terhadap behavioral intention dengan t-statistics lebih dari 1.96 sehingga terbukti signifikan. Efek moderasi age (usia) pada pengaruh facilitating condition dan price value terhadap behavioral intention, menghasilkan koefisien positif sehingga dapat dikatakan bahwa efek moderasi age (usia) pada pengaruh facilitating condition dan price value terhadap behavioral intention terbukti positif signifikan. Age (usia) tidak memoderasi pengaruh perfornance expectancy, effort expectancy, social influence, dan hedonic motivation karena memiliki nilai t-statistics kurang dari 1.96 sehingga tidak terbukti signifikan. 
Hal ini berarti terdapat perbedaan pandangan antara pria dan wanita terkait performance expectancy, social influence, dan price value terkait penggunaan Home Digital Service PT. TELKOM. Koefisien path yang negative pada performance expectancy dan price value menunjukkan bahwa pengaruh perforrnance expectancy dan price value terhadap behavioral Intention pada pria lebih rendah daripada pengaruh performance expectancy dan price value terhadap behavioral intention pada wanita. Sementara pengaruh social influence terhadap behavioral intention pada pria lebih tinggi daripada pengaruh social influence terhadap behavioral intention pada wanita karena memiliki koefisien path positif.

Jadi upaya-upaya social campaign Home Digital Service PT. TELKOM sebaiknya lebih ditujukan bagi konsumen pria. Misalnya dengan mengadakan 'nobar' (nonton bareng) pertandingan sepak bola (liga Inggris, timnas Indonesia, dsb) bersama UseeTV dan TELKOM. Sementara upaya-upaya pemasaran yang menonjolkan kehandalan, manfaat, serta kelayakan harga Home Digital Service PT. TELKOM sebaiknya lebih ditujukan bagi konsumen wanita. Oleh karena itu TELKOM harus lebih memahami kebutuhan wanita dan apa saja yang memudahkan pekerjaan para wanita yang menjadi konsumen Home Digital Service PT. TELKOM. Apabila wanita tersebut adalah ibu rumah tangga, konten-konten Speedy internet atau UseeTV sebaiknya membantu pekerjaan ibu rumah tangga seperti tips merawat rumah, anak, dan acara memasak ataupun resep-resep makanan terbaik. Nilai harga juga lebih ditekankan pada wanita karena pada umumnya wanita lebih sensitive terhadap harga dan cenderung lebih berusaha keras mendapatkan harga termurah untuk kualitas terbaik, lebih daripada pria. Terbukti dari fakta bahwa wanita lebih suka dan pandai menawar harga termurah. Selain itu, sebagaimana dikatakan oleh Venkatesh et.al. (2012) bahwa wanita pada umumnya adalah pemegang keuangan rumah tangga suatu keluarga dan lebih banyak pertimbangan dalam mengeluarkan uang untuk kebutuhan rumah tangganya.

Kemudian variabel moderator age (usia) hanya terbukti signifikan memoderasi pengaruh variabel facilitating condition dan price value terhadap behavioral intention. Efek moderasi age (usia) pada pengaruh facilitating condition dan price value terhadap behavioral intention menghasilkan koefisien positif sehingga dapat dikatakan bahwa efek moderasi age (usia) pada pengaruh facilitating condition dan price value terhadap behavioral intention terbukti positif signifikan. Age (usia) tidak memoderasi pengaruh expectancy, effort expectancy, social influence, dan hedonic motivation dan tidak terbukti signifikan.

Efek moderasi usia pada pengaruh facilitating condition dan price value terhadap behavioral intention prospective users Home Digital Service PT. TELKOM memiliki arti adanya perbedaan pandangan antara usia muda (14-25 tahun) dengan usia (>25-62 tahun). Pengaruh facilitating condition dan price value terhadap behavioral intention prospective users Home Digital Service PT. TELKOM memiliki koefisien path positif yang menunjukkan bahwa pengaruh facilitating condition dan price value terhadap behavioral intention prospective users usia muda (14-25 tahun) lebih tinggi daripada pengaruh facilitating condition dan price value terhadap behavioral intention prospective users usia tua (>25-62 tahun).

Hal tersebut menunjukkan bahwa service centre Home Digital Service TELKOM sebaiknya lebih bergaya anak muda dengan suasana serta gaya pelayanan yang lebih casual sehingga konsumen usia muda lebih nyaman berada disana. Selain itu, konsumen usia muda lebih sensitive terhadap nilai harga karena pada umumnya mereka adalah pelajar, mahasiswa, dan karyawan baru dengan uang saku yang terbatas sehingga harus berpikir berulang kali untuk mengeluarkan uangnya. Selain itu konsumen usia muda cenderung lebih sadar teknologi sehingga lebih kritis terhadap teknologi-teknologi dan layanan-layanannya. Sehingga layanan-layanan dan harga bagi konsumen usia muda harus lebih disesuaikan misalnya bundling konten entertainment UseeTV, Melody Online, dan Speedy Internet dengan harga yang lebih bersahabat bagi kantong pelajar/mahasiswa. Selain itu dapat pula menggunakan speedy card khusus pelajar/mahasiswa. 


\section{KESIMPULAN DAN SARAN}

\section{Kesimpulan}

Berdasarkan hasil pengolahan dan analisis data serta pengujian hipotesis yang telah dilakukan dalam penelitian Pengaruh Faktor-Faktor dalam Modified Unified Theory of Acceptance and Use of Technology 2 (UTAUT 2) terhadap Niat Prospective Users untuk Mengadopsi Home Digital Service PT. TELKOM di Surabaya, sesuai rumusan masalah dan tujuan penelitian, peneliti dapat menyimpulkan hal-hal sebagai berikut:

1. Faktor-faktor dalam Modified Unified Theory of Acceptance and Use of Technology 2 (Modified UTAUT2) dalam penelitian ini terbukti positif signifikan mempengaruhi niat prospective users untuk mengadopsi Home Digital Service di Surabaya. Faktorfaktor tersebut antara lain: performance expectancy, effort expectancy, social influence, facilitating condition, hedonic motivation, dan price value.

2. Besar pengaruh factor-faktor dalam Modified Unified Theory of Acceptance and Use of Technology 2 (Modified UTAUT2) terhadap niat (behavioral intention) prospective users untuk mengadopsi Home Digital Service di Surabaya mulai dari yang terbesar hingga terkecil adalah: hedonic motivation (0.260), social influence (0.194), price value (0.138), facilitating condition (0.116), effort expectancy (0.094), performance expectancy (0.90). Angka-angka ( $n$ ) tersebut adalah besar pengaruh masing-masing faktor eksogen yang artinya bila faktor eksogen meningkat satu satuan maka behavioral intention akan menigkat sebesar satuan.

3. Gender atau jenis kelamin dalam Modified Unified Theory of Acceptance and Use of Technology 2 (Modified UTAUT2) terbukti signifikan memoderasi pengaruh performance expectancy, social influence dan price value terhadap niat prospective users untuk mengadopsi Home Digital Service di Surabaya. Sementara factor usia dalam Modified Unified Theory of Acceptance and Use of Technology 2 (Modified UTAUT2) terbukti signifikan memoderasi pengaruh facilitating condition dan price value terhadap niat prospective users untuk mengadopsi Home Digital Service di Surabaya.

4. Modified Unified Theory of Acceptance and Use of Technology 2 (Modified UTAUT2) dalam penelitian ini memiliki nilai R-square sebesar 0.548 , artinya presentase besarnya behavioral intention yang dapat dijelaskan oleh performance expectancy, effort expectancy, social influence, facilitating condition, hedonic motivation, dan price value adalah sebesar $54 \%$. Sedangkan $45.2 \%$ dijelaskan oleh variabel lain yang tidak diteliti di dalam penelitian ini. Hal tersebut menunjukkan bahwa Modified UTAUT 2 dalam penelitian ini dapat dipakai untuk memprediksi niat prospective users untuk mengadopsi Home Digital Service PT. TELKOM di Surabaya. Kemampuan prediksi Modified UATUT 2 sebesar 54.8\% dalam penelitian ini termasuk ke dalam kategori moderat.

\section{Saran}

Berdasarkan hasil penelitian, PT. TELKOM dapat mendesain produk Home Digital Service yang mudah digunakan, menyenangkan dan menghibur, memiliki harga sesuai dengan kantong konsumen serta sesai dengan manfaat yang diberikan. Desain produk dan pemasaran yang mempertimbangkan dan menonjolkan keenam hal berdasarkan UTAUT 2 akan meningkatkan niat para prospective users untuk mengadopsi Home digital Service PT. TELKOM.

PT. TELKOM juga harus memperhatikan perbedaan pandangan antara prospective users pria dan wanita serta prospective users usia muda ( $14-25$ tahun) dan tua ( $>5-62$ tahun). Gender atau jenis kelamin terbukti signifikan memoderasi pengaruh performance expectancy, social influence, dan pice value terhadap niat prospective users untuk mengadopsi Home Digital Service PT. TELKOM di Surabaya. Sementara age atau usia dalam Modified Unified Theory of Acceptance and Use of Technology 2 (Modified UTAUT2) terbukti signifikan memoderasi pengaruh facilitating condition dan price value terhadap niat prospective users. PT. TELKOM 
sebaiknya lebih menonjolkan kehandalan atau manfaat produk, dan nilai harga atau benefit yang dapat dirasakan konsumen kepada prospective users wanita. Keberadaan komunitas, viral

JURNAL

MANAJEMEN INDONESIA

Vol. 12 - No. 4 April 2013

marketing, dan penetrasi sosial media sebaiknya lebih ditujukan bagi konsumen pria.

Penulis menyarankan agar penelitian berikutnya dapat dilakukan di kota lain selain Surabaya yang menjadi target pasar Home Digital Service PT Telkom seperti Semarang, Bandung, Palembang, Medan, Batam, Pekanbaru, Makassar, dan Banjarmasin. Penelitian selanjutnya juga dapat beberapa variabel lain dari teori-teori sebelumnya seperti: teori IDT (relative advantage, compatibility, complexity, triability, observability), teori MPCU (job-fit, complexity, long term consequences, affect toward use), teori SCT (outcome-expectation performance, outcome-expectation personal, self-efficacy, affect, dan anxiety) teori TAM (perceived usefulness, perceived ease of use, output quality, result demonstrability, job relevance, image). Selain itu dapat pula menambahkan variable-variabel pengembangan teori lainnya seperti content, trust in company, trust in technology, perceived credibility, perceived financial cost, switching cost, dan user satisfaction. Sehingga penelitian selanjutnya dapat lebih baik dalam menjelaskan niat prospective users untuk mengadopsi Home Digital Service PT. TELKOM.

\section{DAFTAR PUSTAKA}

Admin. (2013). Broadband. http://digitalkreatif.com/news/broadband. [12 Mei 2013]

Admin. (2013). Industri Internet. http://digitalkreatif.com/news/industry-internet. [12 Mei 2013] Akamai Q4 2012 Report. http://www.akamai.com/stateoftheinternet. [12 Mei 2013]

Alshehri, Mohammad, Steve Drew, Thamer alhussain, Rayed Alghamdi. (2012). The Effects of Website Quality on Adoption of E-Government Service: An Empirical Study Applying UTAUT Model Using SEM. 23rd Australasian Conference On Information System.

Armida, Eduardo Esteva. (2008). Adoption Process for VOIP:The Influence of Trust in The UTAUT Model. Disertai Doktor pada purdue University west Lafayette Indiana: diterbitkan.

Awuah, Lawrence J. (2012). An Empirical Analysis of Citizens Acceptance Decision of Electronic Government Service: A Modification of the Unified Theory of Acceptance and Use of Technology (UTAUT) Model to Include Trust As A Basis For Investigation. Disertai Doktor pada School of Business and Technology Capella University: diterbitkan.

Dharmabotla, VenkataSraven K. (2011). Exploring The Determinant of Perceived Value of Smartphone in A Value Co-Creation Ecosystem From Service Dominant Logic Perspective. Tesis master of Science pada University of Houston-Clear Lake:diterbitkan.

Filloon, Gerard, Hassen Braham, Jean-Pierre Booto Ekionea. (2011). Testing UTAUT on The Use of ERP Sytem by Middle Managers and End Users of Medium to Large Sized Canadian Enterprises. Academy of Information and Management Sciences Journal, Vol. 14(1): 1-28.

Foon, Yeoh Sok, Benjamin Chan Yin Fah. (2011). Internet Banking Adoption in Kuala Lumpur: An Application of UTAUT Model. International Journal of Business Management, Vol. 6(4): 161-167.

Ghozali, Imam. (2008). Structural Equation. Modeling Metode Alternatif dengan Partial Least Square. Semarang: Universitas Diponegoro.

Gonzales, George C., Pratyush Nichi Sharma Dennis Galletta. (2012). Factors Influencing The Planned Adoption of Continucus Monitoring Technology. Journal of Information System, Vol. 26(2): 53-69.

Hamidfar, Mabod. (2008). Adoption of Electronic Patient Records by Iranian Hospitals Staff. Tesis Master pada Department of Business Administration and Social Sciences Division of Industrial Marketing and E-Commerce Lulea University of Technology: diterbitkan.

Hatta. (2012). http://wartaekonomi.co.id/berita4775/ini-peringkat-kabupatenkota-terkaya-2012. html. [7 Mei 2013] 
Hill, Sally Rao, Barry Burgan, Indrit Troshani. (2011). Understanding Broadband Adoption in Rural Australia. Journal of Industrial Management \& Data Systems, Vol. 111(7): 1087-1104.

Indrawati, Murali Raman, Kok-Wai Chew. (2010). A Conceptual Model for Behavioral Intention to Use 3G Mobile Multimedia Services in Indonesia. iEEE, Special Issue.

Jajeli, Rois (2012). Akses Broadband di Surabaya Masih Rendah. http://inet.detik.com/read/2012 /01/11/091533/1812245/328/akses-broadband-di-surabaya-masih-rendah. [7 Mei 2013]

Jogiyanto, HM. (2011). Konsep dan Aplikasi Structural Equation Modelling Berbasis Vanan Dalam Penelitian Bisnis. Yogyakarta: UPP STIM YKPN.

Khristianto, Wheny, dan Suprihatin Ali. (2009). Pengujian Model Penerimaan Mahasiswa Administrasi Bisnis Terhadap Penggunaan Internet Sebagai Media Untuk Pemasaran Produk (3-marketing). Jurnal Bisnis dan Manajemen, Vol. 5(2): 101-198.

Kiriakou, Charles M. (2012). Acceptance Factors Influencing Adoption of National Institute of Standards and Technology Information Security Standards: A Quantitative Study. Disertasi Doktor pada School of Business and Technology Capella University: diterbitkan.

Krisdiastoro. (2009). Analisis Penerimaan Pengguna Terhadap Sistem Informasi TeNOSS di PT. Telekomunikasi Indonesia, Tbk. Tesis Megister Manajemen pada Sekolah Pascaserjana IM Telkom: tidak diterbitkan.

Kurniawan, Heri, dan Sofyan Yamin. (2011). Generasi Baru Mengolah Data Penelitian dengan Partial Least Square Path Modeling Aplikasi dengan Software XLSTAT, SmartPLS, dan Visual PLS. Jakarta: Salemba Infotek.

Lee, Hyun-Joo, Heejin Lim, dan Jolly Laura D. Jolly. (2009). Consumer Lifestyles and Adoption of High-Technology Products: A Case of South Korea. Journal of International Consumer Marketing, Vol. 21: 153-167.

Librianty, Andina. (2012). 2012, Pengguna Internet di Indonesia Tembus 63 Juta. http://techno. okezone.com/read/2012/12/12/55/731115/. [15 Juli 2013]

Macharia, Alice W. (2011). Toward Adoption of Electronic Learning An Empirical Ivestigation of Faculty Behavioral Intentions. Disertai Doktor pada School of Business and Technology Capella University: diterbitkan.

Menkominfo: Jaringan Pita Lebar, Katalisator Perekonomian Indonesia. (2012). http://portal. kominfo.go.id/berita/kini/49. [12 Maret 2013]

Moghavvemi, Sedigheh, Noor A Mohd Saleh, Wenjie Zhao, dan Minna Matilla. (2012). The Entrepreneur's Perfection on Information Technology Innovation Adoption: An Empirical Amalysos of The Role of Precitipitating Events on Usage Behavior. Innovation: Management, Policy, and Practice, Vol. 14(2): 231-246.

Muhayiddin, Mohd-Nazri, Elsadig Musa Ahmed, Hishamuddin Ismail. (2011). Technology Acceptance of Gold Dinar Based Electronic Payment System. iBusiness, Vol. 3: 295-301.

PT Telkom. (2010). TELKOM Mulai Operasikan Home Digital Service. http://www.telkom.co.id/ pojok-media/siaran-pers/telkom-mulai-operasikan-home-digital-service.html. [15 Juli 2013]

Pratt, Robert C. (2010). Factors Affecting Use of Instant Messaging Software by Information Technology Professional. Disertasi Doktor pada Applied Management and Decision Sciences Faculty Walden University College of Management and Technology: diterbitkan.

Sandaire, Johnny. (2009). Usage Intention Framework Model: Fuzzy Logic Interpretation of The Classical UTAUT Model. Disertasi Doktor pada Computer Science With A Concentration in Enterprise Information System Faculty of Colorado Technical University: diterbitkan.

Savitri, Ayunda. (2013). Telkkom-Intel Jembatani Masyarakat Menuju Era Digital. http://techno. okezone.com/read/2013/05/08/54/803976/telkom-intel-jembatani-masyarakat-menujuera-digital. [12 Mei 2013]

Sawyer, Steve, J. P. Allen, Haejin Lee. (2003). Broadband and Mobile Opportunities: a SocioTechnical Perspective. Journal of Information Technology, Vol. 18: 121-136.

Shu, Wesley dan Yu-Hao Chuang. (2011). The Behavior of Wiki Users. Social behavior and Personality, Vol. 39(6): 851-864.
JURNAL

MANAJEMEN INDONESIA

Vol. 12 - No. 4 April 2013 
Subandrio, Agus. (2011). Nusantara Super Highway TELKOM Readiness to Provide ICT Connectivity. http://www.mastel.or.id/flies/Nusantara\%20Super\%20Highway\%20 Mastel\%20Seminar\%2029-11-2011.pdf. [12 Mei 2013]

JURNAL

MANAJEMEN

INDONESIA

Vol. 12 - No. 4

April 2013

Suryadhi, Ardhi. (2011). 4 Kriteria Kota Digital., http://inet.detik.com/ read/2011/10/27/082513/1753567/328/4-kriteria-kota-digital. [7 Mei 2013]

Target Perkembangan Broadband di Indonesia. (2012). http://portal.kominfo.go.id/berita/ kini/49. [12 Maret2013]

Telkom $3^{\text {rd }}$ Quarterly Result Report. Telkom www.telkom.ac.id. [10 Maret 2013]

Venkatesh, Viswanath, Xica Jun Zhang. (2010). Unified Theory of Acceptance and Use Technology: U.S. Vs. China. Journal of Global Information Technology Management, Vol. 13(1): 5-27.

Venkatesh, Viswanath, James Y. L. Thong, Xin Xu. (2012). Consumer Acceptance and Use of Information Technology: ExtendingThe Unified Theory of Acceptance and Use of Technology . MIS Quarterly: Vol. 36(1): 157-178.

Wang, Hsiu-Yuan, Shwu-Huey Wang. (2010). User Acceptance of Mobile Internet Based on The Unified Theory of Acceptance and Use of Technology: Investigating The Determinants and Gender Differences. Social Behavior and Personality, Vol. 38(3): 415-426.

Wolfenden, Andrew. (2012). Factors Predicting Oncology Care Providers Behavioral Intention To Adopt Clinical Decision Support Systems. Disrtasi Doktor pada School of advanced Studies University of Phoenix: diterbitkan.

Wu, Mei-Ying, Pei Yuan Yu, dan Yung-Chien Weng. (2012). A Study on User Behavior for I Pass by UTAUT: Using Taiwan's MRT As An Example. Asia Pacific Manajement Review, Vol. 17(1): 91-111.

Yang, Kiseol. (2010). Determinants of US Consumer Mobile Shopping Services Adoption: Implication for Designing Mobile Shopping Services. Journal of Consumer Marketing, Vol. 27(3): 262-270.

Yu, Chian-Son. Factors Affecting Individuals to Adopt Mobile Banking: Empirical Evidence From The UTAUT Model. (2012). Journal of Electronics Commerce Research, Vol. 13(2): 104-121. 